\title{
VERSIT^ 10.2478/v10310-012-0030-5 \\ Exploiting of the phenoxazine as first - ever use ligand in rapid spectrophotometric methods for the determination of chromium(VI) in environmental samples
}

\author{
Mansour S. ABDUL GALIL* and Riyad Ahmed AL OKAB
}

Chemistry Department, Faculty of Applied Science, Taiz University, Taiz, Republic of Yemen

\begin{abstract}
Two new rapid, accurate, sensitive, reproducible and economical spectrophotometric methods are described for the determination of hexavalent chromium in bulk and in environmental samples like, water and soil using two new electrophilic coupling spectrophotometric reagents, 2-amino-2',5-dichlorobenzophenone (MCB) and 2-amino-5-chloro-2'-fluorobenzophenone (MFB) and first-ever use phenoxazine (PNZ). Both methods are based on the oxidation of (MCB) or (MFB) by chromium(VI) in hydrochloric acid medium and coupling with PNZ to yield red colored, which are stable for about $12 \mathrm{~h}$ and have an absorbance maximum 520 $\mathrm{nm}$. Beer's law is obeyed for chromium(VI) in the concentration ranges $0.15-1.20 \mu \mathrm{g} \mathrm{mL}^{-1}$ and $0.17-1.41 \mu \mathrm{g} \mathrm{mL}$ ${ }^{1}$ respectively. The optimum reaction conditions and other important analytical parameters were established to maximize sensitivity of these methods. Interference by various non-target ions was also investigated. The performance of these methods was further evaluated by recovery tests applying standard addition method, which indicated that there is no significant difference between the proposed methods and the standard reference spectrophotometric method.
\end{abstract}

Keywords: spectrophotometry, hexavalent chromium, phenoxazines, environmental samples

\section{Introduction}

Chromium is one of the most abundant elements on earth and is naturally present in rocks, soil, plants, animals, volcanic dust and gases [1-4]. It occurs in oxidation states ranging from -2 to +6 [5].

Chromium is released into the environment from various natural and industrial sources [6], which is widely used in industrial activities such as chrome plating and electroplating, metal smelting and metallurgy to manufacture alloys, dyestuff industries, leather tanning and wood treatment $[7,8]$.

The hexavalent chromium exists in surface waters in different species depending on the $\mathrm{pH}$ range of this waters, where the primary hydrolyzed forms are chromic acid $\left(\mathrm{H}_{2} \mathrm{CrO}_{4}\right)$, hydrogen chromate ion $\left(\mathrm{HCrO}_{4}^{-1}\right)$, chromate ion $\left(\mathrm{CrO}_{4}^{-2}\right)$, and dichromate ion $\left(\mathrm{Cr}_{2} \mathrm{O}_{7}{ }^{2-}\right)$ [6].

Chromium can be both beneficial and toxic to animals and humans depending on its oxidation state and concentration [9]. The hexavalent chromium is highly soluble, mobile and bioavailable compared with trivalent chromium species and has toxic and carcinogenic effects to humans and animals [10], and is present as an air, soil, and water-pollutant. Because of its strong oxidizing potential and easy permeation of biological membrane the hexavalent chromium damages the macromolecules, proteins and the DNA [10].

Although the Environmental Protection Agency (EPA) of USA has set the maximum level of total chromium allowed in drinking water at $100-\mathrm{g} / \mathrm{L}$, the chromium content is normally presented at very low concentration in natural waters, where typical concentrations are in the $0.1-0.5 \mathrm{~g} / \mathrm{L}$ range. Therefore, the direct determination of trace chromium species in environmental samples demands very sensitive analytical techniques [5].

Hexavalent chromium is an essential nutrient element necessary for maintaining normal physiological functions [11], unlike, hexavalent chromium, which is toxic [12]. 
Due to the importance of hexavalent chromium species as a toxic pollutant with mutagenic and carcinogenic effects, it is essential to determine it and the total chromium concentration using a rapid and simple method that can be applied in industrial and environmental fields as in our proposed methods.

There are various methods, which have exploited organic reagents for chromium spectrophotometric determination, but some of them require either a heating step for colour development $[13,14]$ or require strictly controlled experimental conditions or are of high blank value [15-19] or that the reagents used are of carcinogenic properties [20]. Numerous solvent extraction procedures have been suggested for the determination of chromium $[21,22]$, but these methods are lengthy, time consuming and lacks sensitivity due to much interference[23]. Besides, there are many instrumental methods such as ICP-MS [24,25], ICPAES [26,27], and AAS [28,29], but they are disadvantageous in terms of cost and unavailable in some laboratories, while some of them such as AAS are often lacking in sensitivity and affected by matrix conditions of samples such as salinity. Although, the diphenylcarbazide [30-32] is considered the famous spectrophotometric reagent for the determination of hexavalent chromium, it suffers serious interferences from many cations namely, $\mathrm{Fe}(\mathrm{III}), \mathrm{Mo}(\mathrm{VI}), \mathrm{Cu}(\mathrm{II})$, and $\mathrm{Hg}$ (II) [30,33], and also the formed complex is stable for only 30 min in the presence of a phosphate buffer [34]. Hence, the present work aims to present simple, rapid, inexpensive, sensitive, high reliability and reproducibility methods for the determination of hexavalent chromium in various environmental samples. The methods are based on the oxidation of (MCB) or (MFB) by hexavalent chromium in hydrochloric acid medium and coupling with PNZ to yield red colored, which are stable for about $12 \mathrm{~h}$ and have an absorbance maximum $520 \mathrm{~nm}$.

\section{Experimental}

\subsection{Materials and apparatus}

Specord $50 \mathrm{UV}-\mathrm{Vis}$ spectrophotometer with 1.0 $\mathrm{cm}$ silica quartz matched cell (Jasco, Tokyo, Japan) was used for measuring the absorbance.
All chemicals used were of analytical reagent grade, and distilled water was used throughout the study. The reagents were used without further purification. Phenoxazine (PNZ), 2-amino-2',5dichlorobenzophenone(MCB) and 2-amino-5chloro-2'-fluorobenzophenone (MFB) were obtained from Aldrich.

Standard chromium (VI) stock solution $(1000 \mu \mathrm{g}$ $\mathrm{mL}^{-1}$ ) was prepared by dissolving known quantity of potassium dichromate, $0.2830 \mathrm{~g}$ in $100 \mathrm{~mL}$ of distilled water. More dilute solutions of the reagent were prepared as required.

Standard chromium(III) stock solution(1000 $\mu \mathrm{g}$ $\mathrm{mL}^{-1}$ ) was prepared by dissolving $0.2830 \mathrm{~g}$ of $\mathrm{K}_{2} \mathrm{Cr}_{2} \mathrm{O}_{7}$ in $50 \mathrm{~mL}$ of water, adding $1 \mathrm{~mL}$ saturated sodium sulfite solution, acidifying with $1 \mathrm{~mL}$ of 2.5 mol L $\mathrm{L}^{-1}$ sulfuric acid, and then boiling for $2 \mathrm{~min}$ to remove excess sulphur dioxide and diluting with water to $100 \mathrm{~mL}$. Suitable volume of this solution was diluted to obtain the working standard [23].

Fresh PNZ solution $0.025 \%$ (w/v) was prepared by dissolving $25 \mathrm{mg}$ of each sample separately in $100 \mathrm{~mL}$ distilled ethyl alcohol.

(MCB) and (MFB) solutions $0.05 \%(w / v)$ were prepared by dissolving $50 \mathrm{mg}$ of the samples individually in $100 \mathrm{~mL}$ of distilled ethyl alcohol.

The other solutions of reagents were prepared by dissolving appropriate amounts of reagents in distilled water.

\subsection{General procedures}

\subsubsection{Determination of hexavalent chromium}

To a series of $25 \mathrm{~mL}$ calibrated flasks, $1.0 \mathrm{~mL}$ of $0.05 \%(\mathrm{w} / \mathrm{v})(\mathrm{MCB})$ or $(\mathrm{MFB})$ reagent, an aliquots of standard solutions of hexavalent chromium, $2.0 \mathrm{~mL}$ of $0.025 \%$ (w/v) PNZ and 1.0 $\mathrm{mL}$ of $2 \mathrm{~N}$ hydrochloric acid were added. The contents were mixed thoroughly and allowed for 5 min to complete the reaction. The resultant red colored solutions in the standard flasks were made up to the volume with distilled water. Absorbance was measured at $520 \mathrm{~nm}$ for PNZ with $1.0-\mathrm{cm}$ quartz cell against the corresponding reagent blank, which was prepared similarly except for the addition of chromium(VI). The optical characteristics for determination of hexavalent chromium with PNZ using (MCB) and (MFB) are shown in Table 1. 
Table 1. Spectral data for determination of chromium(VI) using MCB/ MFB as electrophilic coupling agents and PNZ as chromogens

\begin{tabular}{|c|c|c|}
\hline Parameters & $\begin{array}{l}\mathrm{PNZ}+ \\
\mathrm{MCB}\end{array}$ & $\begin{array}{l}\text { PNZ+ } \\
\text { MFB }\end{array}$ \\
\hline Color & Red & Red \\
\hline$\lambda \max (\mathrm{nm})$ & 520 & 520 \\
\hline Stability (h) & 12 & 12 \\
\hline Beer's law $\left(\mu \mathrm{g} \mathrm{mL}^{-1}\right)$ & $0.15-1.20$ & $0.17-1.41$ \\
\hline $\begin{array}{l}\text { Recommended ion } \\
\text { concentration }\left(\mu \mathrm{g} \mathrm{mL}^{-1}\right)\end{array}$ & 0.50 & 0.70 \\
\hline $\begin{array}{l}\text { Molar absorptivity (L } \\
\left.\mathrm{mol}^{-1} \mathrm{~cm}^{-1}\right) \times 10^{4}\end{array}$ & 2.81 & 6 \\
\hline $\begin{array}{l}\text { Sand ell's sensitivity } \\
\left(\mu \mathrm{g} \mathrm{cm}^{-2}\right) \times 10^{-3}\end{array}$ & 1.89 & 1.95 \\
\hline \multicolumn{3}{|l|}{ Regression equation*: } \\
\hline Slope (a) & 0.723 & 0.617 \\
\hline Intercept (b) & -0.061 & -0.052 \\
\hline Correlation coefficient & 0.9992 & 0.9892 \\
\hline Reaction time (min) & 5 & 5 \\
\hline $\mathrm{RSD} \%(\mathrm{n}=7)$ & 0.50 & 0.56 \\
\hline
\end{tabular}

Regression curve: $y=a x+b$ where $x$ is the concentration of chromium(VI) in $\mu \mathrm{g} m L^{-1}$ and $y$ is absorbance

\subsubsection{Determination of trivalent chromium}

To a series of $25 \mathrm{~mL}$ calibrated flasks, an aliquot of a sample solution containing $0.15-1.20$ in the case of using (MCB) and $0.17-1.41 \mu \mathrm{g} \mathrm{mL}^{-1}$ in the case of using (MFB) of trivalent chromium, 0.5 $\mathrm{mL}$ saturated bromine water and $0.5 \mathrm{~mL}$ of $4.5 \mathrm{~mol}$ $\mathrm{L}^{-1} \mathrm{KOH}$ solution were added and allowed to stand for $5 \mathrm{~min}$. Then $0.5 \mathrm{~mL}$ of $2.5 \mathrm{~mol} \mathrm{~L}^{-1}$ sulfuric acid and $0.5 \mathrm{~mL}$ of $5 \%$ sulfosalicylic acid were added and then above procedure for trivalent chromium was followed.

\section{Results and Discussions}

\subsection{Absorption spectra of colored derivatives}

In order to have minimum interferences, it was necessary to identify optimum wavelength for hexavalent chromium determination in the proposed methods. This wavelength must be specific for the quantitative and specific monitoring of the (MCB)/(MFB)-Cr(VI)-PNZ over the range 300-800 $\mathrm{nm}$ with a Specord 50-UV-Vis spectrophotometer. Wavelengths of $520 \mathrm{~nm}$ were found optimum to get best results (Fig. 1).

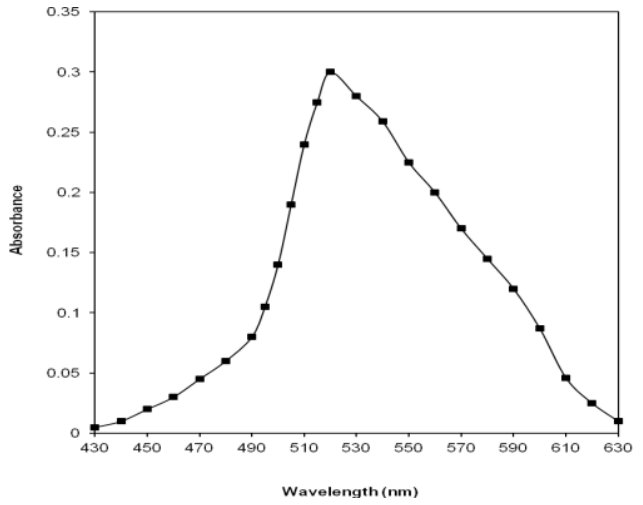

Fig. 1. The optimum wavelengths of the red colored compounds formed between (MCB) or (MFB) and

PNZ in the presence hexavalent chromium

\subsection{Reaction mechanism}

The chemical reaction in the spectrophotometric study, involved the reduction of chromium(VI) by (MCB) or (MFB) and the latter's subsequent oxidative coupling with PNZ in an acidic medium to form a red product. A proposed reaction mechanism is shown in Scheme 1. The factors affecting the color development, reproducibility, sensitivity and adherence to Beer's Law were investigated by optimizing the analytical variables.

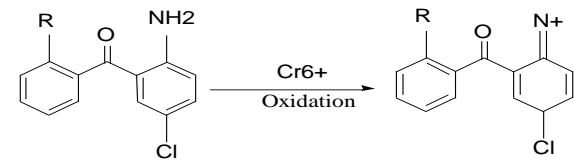<smiles></smiles><smiles>[R]c1ccc2c(c1)Nc1ccc(/N=C3/C=CC(Cl)C=C3C(=O)c3ccccc3[R])cc1O2</smiles>

Scheme 1: The proposed mechanism of the oxidative reaction of (MCB) or (MFB) by hexavalent chromium in hydrochloric acid medium and coupling with PNZ reagent. 


\subsection{Effect of reagents and acid concentration}

The effect of PNZ reagent at $0.025 \%(\mathrm{w} / \mathrm{v})$ solution in the range of $0.10-10.0 \mathrm{~mL}$ was studied to find the volume needed to get maximum color intensity. The results indicated that $1.0-3.0 \mathrm{~mL}$ of the solution was necessary. Hence, $2.0 \mathrm{~mL}$ of $0.025 \%(\mathrm{w} / \mathrm{v})$ solution in a $25 \mathrm{~mL}$ standard flask was taken. Maximum intensity of the red color was achieved in hydrochloric acid medium. Preliminary investigations showed that hydrochloric acid was better than sulphuric, phosphoric or acetic acid. Maximum intensity of the red color was achieved in the range of $0.5-2.0 \mathrm{~mL}$ of $1 \mathrm{M} \mathrm{HCl}$. Therefore, 1.0 $\mathrm{mL}$ of $1 \mathrm{M} \mathrm{HCl}$ in $25 \mathrm{~mL}$ was used for getting best results. Similarly, the amount of (MCB) or (MFB) for constant and maximum color development was investigated. It was found that $1.0-3.0 \mathrm{~mL}$ of the solution was necessary. Hence, $2.0 \mathrm{~mL}$ of $0.05 \%$ $(w / v)$ (MCB) or (MFB) was selected to get reproducible results.

Experiments were carried out to optimize temperature and time of the reaction. It was found that maximum color intensity developed within 5 min at room temperature and remained almost stable for about $12 \mathrm{~h}$. Increase in reaction temperature decreased the intensity of red color. Hence, 5 min reaction was selected for the routine analysis.

\subsection{Order of addition of reactants}

During the investigation it was observed that the sequence of addition of reactants was also important as it influenced the intensity and the stability of the color of the product to a great extent. The sequences (i) PNZ-HCl-Cr(VI)-(MCB) or (MFB) and (ii) $\mathrm{Cr}(\mathrm{VI})-\mathrm{HCl}-\mathrm{PNZ}(\mathrm{MCB})$ or (MFB) gave less intense and unstable color. While, more intense and stable red color was obtained with sequence (iii) (MCB) or (MFB)-Cr(VI)-PNZ-HCl. This was expected as the reaction (i) and (ii) produced radical cation while, in (iii) electrophilic reaction was involved.

\subsection{Linearity, accuracy and precision}

The spectrophotometric methods were further evaluated under the optimum conditions with regard to linearity, accuracy, and precision, molar absorptivity and Sandell's sensitivity.

The linearity of the spectrophotometric method for the determination of chromium(VI) was evaluated under the optimum conditions. The regression calibration equation obtained under optimum conditions for chromium(VI), PNZ and (MCB) was: $\mathrm{Y}=-0.061+0.723 \mathrm{X} ; \mathrm{r}=0.9992$ and $\mathrm{n}=5$. Where, $\mathrm{Y}$ is the absorbance and $\mathrm{X}$ the chromium(VI) concentration in $\mathrm{mg} / \mathrm{L}$. The calibration curve was linear over the range $0.15-1.20 \mathrm{mg} / \mathrm{L}$. The molar absorptivity was $2.81 \times 10^{4} \mathrm{~L} \mathrm{~mol}^{-1} \mathrm{~cm}^{-1}$ for PNZ (MCB) complex and Sandell's sensitivity was $0.00189 \mathrm{mg} \mathrm{cm}^{-2}$.

The accuracy of the method was evaluated by taking real environmental samples like lake, well, and tap waters and soil samples and the results were compared with standard spectrophotometric method results. The results obtained in the proposed spectrophotometric methods compared very well with those from the standard method [35]. The \% R.S.D. was found to be $<0.6(n=7)$.

To further confirm the validity and accuracy of the proposed method, recovery tests were performed by standard addition method. Each test was repeated five times. The results presented in Tables 2 indicate very good recoveries and non-interference from commonly encountered constituents normally present in the environmental samples.

\subsection{Effect of diverse ions}

In order to establish the analytical potentiality of proposed method, the effect of some possible interfering ions, which often accompany chromium(VI) was examined by the proposed methods. Any ion is considered to be interfering with the determination, only when the absorbance value differs by $\pm 3 \%$ from that of chromium(VI) alone. Metals such as iron(III), vanadium(V), manganese(VII) and cerium(IV), and non metals like bromate, iodate and periodate were found to interfere severely as they caused low recovery of chromium(VI). Masking agents like EDTA, tartrate and citrate have not interfered in the determination of chromium(VI). Therefore, $2.0 \mathrm{~mL}$ of $2 \%$ EDTA were used to mask the interference by the above stated interfering metals. During the interference studies, if any precipitate was formed, it was overcome by centrifugation. The possible interference and the maximum tolerable concentrations are listed in Table 3. 
Table 2. Determination of chromium(VI) in different water and soil samples using PNZ/MCB

\begin{tabular}{|c|c|c|c|c|c|c|c|}
\hline \multirow[t]{2}{*}{ Sample } & \multirow{2}{*}{$\begin{array}{c}\mathrm{Cr}(\mathrm{VI}) \\
\text { added } \\
\left(\mu \mathrm{g} \mathrm{mL} \mathrm{m}^{-1}\right)\end{array}$} & \multicolumn{2}{|c|}{ Proposed method } & \multicolumn{2}{|c|}{ Reterence method $^{[35]}$} & \multirow[t]{2}{*}{$t$-Value $\mathrm{e}^{\mathrm{b}}$} & \multirow[t]{2}{*}{$F$-Value ${ }^{\mathrm{c}}$} \\
\hline & & $\begin{array}{c}\mathrm{Cr}(\mathrm{VI}) \\
\text { recovered } \\
\left(\mu \mathrm{g} \mathrm{mL} \mathrm{mL}^{-1}\right)\end{array}$ & $\begin{array}{l}\text { Recovery (\%) } \\
\pm \text { R.S.D. }{ }^{\text {a }}\end{array}$ & $\begin{array}{c}\mathrm{Cr}(\mathrm{VI}) \\
\text { recovered } \\
\left(\mu \mathrm{g} \mathrm{mL}^{-1}\right)\end{array}$ & $\begin{array}{l}\text { Recovery (\%) } \\
\pm \text { R.S.D. }\end{array}$ & & \\
\hline \multirow{3}{*}{$\begin{array}{l}\text { Well water } \\
1\end{array}$} & 0.300 & 0.310 & $96.77 \pm 0.78$ & 0.297 & $99.00 \pm 0.72$ & 0.68 & 2.56 \\
\hline & 0.500 & 0.511 & $97.84 \pm 0.68$ & 0.508 & $101.60 \pm 0.67$ & 2.10 & 3.51 \\
\hline & 1.000 & 1.030 & $103.00 \pm 1.28$ & 0.985 & $98.50 \pm 0.91$ & 1.90 & 4.90 \\
\hline \multirow{3}{*}{$\begin{array}{l}\text { Well water } \\
2\end{array}$} & 0.300 & 0.312 & $104.00 \pm 0.95$ & 0.289 & $96.33 \pm 0.57$ & 1.53 & 4.64 \\
\hline & 0.500 & 0.509 & $101.81 \pm 0.72$ & 0.508 & $101.60 \pm 0.67$ & 2.30 & 4.30 \\
\hline & 1.000 & 1.008 & $100.80 \pm 0.52$ & 0.985 & $98.50 \pm 0.91$ & 1.76 & 4.38 \\
\hline \multirow[t]{3}{*}{ Tap water } & 0.300 & 0.297 & $99.00 \pm 1.54$ & 0.310 & $103.33 \pm 0.41$ & 0.68 & 2.56 \\
\hline & 0.500 & 0.508 & $101.60 \pm 1.13$ & 0.509 & $101.81 \pm 0.62$ & 2.10 & 3.51 \\
\hline & 1.000 & 0.985 & $98.50 \pm 0.59$ & 1.008 & $100.80 \pm 0.82$ & 1.90 & 4.90 \\
\hline \multirow{3}{*}{$\begin{array}{l}\text { Farm Land } \\
\text { soil }\end{array}$} & 0.300 & 0.320 & $106.60 \pm 0.88$ & 0.297 & $99.00 \pm 0.30$ & 1.53 & 4.64 \\
\hline & 0.500 & 0.521 & $104.20 \pm 0.79$ & 0.508 & $102.68 \pm 0.28$ & 1.90 & 4.90 \\
\hline & 1.000 & 1.025 & $102.50 \pm 0.88$ & 0.985 & $98.94 \pm 0.53$ & 1.21 & 5.60 \\
\hline \multirow{3}{*}{$\begin{array}{l}\text { Road side } \\
\text { soil }\end{array}$} & 0.300 & 0.297 & $99.00 \pm 0.79$ & 0.308 & $102.67 \pm 0.61$ & 1.30 & 5.32 \\
\hline & 0.500 & 0.508 & $101.60 \pm 0.67$ & 0.488 & $100.44 \pm 0.62$ & 1.53 & 4.64 \\
\hline & 1.000 & 0.985 & $98.50 \pm 0.87$ & 1.091 & $97.62 \pm 0.82$ & 1.90 & 4.90 \\
\hline \multirow{3}{*}{$\begin{array}{l}\text { Manured } \\
\text { garden soil }\end{array}$} & 0.300 & 0.308 & $102.67 \pm 0.97$ & 0.298 & $99.33 \pm 0.75$ & 1.21 & 5.60 \\
\hline & 0.500 & 0.488 & $97.60 \pm 0.89$ & 0.511 & $97.84 \pm 0.53$ & 1.30 & 5.32 \\
\hline & 1.000 & 1.031 & $103.10 \pm 0.83$ & 1.030 & $103.00 \pm 1.20$ & 1.53 & 4.64 \\
\hline
\end{tabular}

$a$ - Average of five-determination. $R S D$ - relative standard deviation.

$b$ - Tabulated $t$-value at $95 \%$ confidence level is 2.78 .

c - Tabulated F-value at $95 \%$ confidence level is 6.39 .

Table 3. Effect of diverse species in the determination of $0.50 \mu \mathrm{g} \mathrm{mL}^{-1}$ of chromium(VI) using proposed PNZ / MCB method

\begin{tabular}{|c|c|}
\hline Foreign ions & $\begin{array}{c}\text { Tolerance limit } \\
\left(\mu \mathrm{g} \mathrm{mL}{ }^{-1}\right)\end{array}$ \\
\hline $\mathrm{Bi}^{3+}, \mathrm{Ba}^{2+}, \mathrm{Ti}^{4+}, \mathrm{EDTA}, \mathrm{Br}$, citrate, tartarate, oxalate & 1000 \\
\hline $\mathrm{Na}^{+}, \mathrm{Mg}^{2+}, \mathrm{Al}^{3+}, \mathrm{Zn}^{2+}, \mathrm{Pb}^{2+}, \mathrm{Cd}^{2+}, \mathrm{K}^{+} \mathrm{Hg}^{2+}, \mathrm{Ni}^{2+}, \mathrm{CH}_{3} \mathrm{COO}^{-}$ & 100 \\
\hline $\mathrm{NO}_{3}, \mathrm{Cl}, \mathrm{Br}^{-}, \mathrm{SO}_{4}{ }^{2}, \mathrm{NH}_{4}{ }^{+}, \mathrm{Co}^{2+}, \mathrm{Cu}^{2+}, \mathrm{PO}_{4}{ }^{3-}$ & 50 \\
\hline $\mathrm{Ch}_{\text {Coramine-T, }}$ Chloramine-B, $\mathrm{IO}_{3}, \mathrm{IO}_{4}, \mathrm{BrO}_{3}$ & 0.2 \\
\hline
\end{tabular}


3.7. Applications. Collection, preparation and determination of chromium(VI) in soil samples

By following static sampling procedure six soil samples were collected at random from a depth of 0 $20 \mathrm{~cm}$ with a distance of about $50 \mathrm{~m}$ between each sampling site.

Known amount of soil $(5.0 \mathrm{~g})$ was taken in a platinum crucible and heated for $3 \mathrm{~h}$ in a muffle furnace at $550^{\circ} \mathrm{C}$. After cooling, transferred the sample into a platinum basin and added $2.0 \mathrm{~mL}$ of double distilled water, $1.0 \mathrm{~mL}$ of concentrated sulphuric acid and $10.0 \mathrm{~mL}$ of concentrated hydrofluoric acid and heated on a sand-bath until vapours of $\mathrm{SO}_{2}$ appeared. The residue was dissolved in $5.0 \mathrm{~mL}$ of double distilled water, acidified to $\mathrm{pH} 3$ with hydrochloric acid [36]. The $\mathrm{pH}$ of the solution was raised to $\sim 10$ by adding concentrated ammonia solution to precipitate the iron and aluminum. Filtered off the precipitate and washed with $3 \mathrm{~mL}$ portions of double distilled water. Evaporated the filtrate to $\sim 20 \mathrm{~mL}$, cooled, acidified the solution to pH 3 with hydrochloric acid, transferred into a 25 $\mathrm{mL}$ standard flask and diluted up to the mark with distilled water. Iron, which is commonly found in most of the soil samples, interferes and its elimination is necessary. Methods reported for the elimination of iron(III), include either precipitation as hydroxide or use of masking agents; the former is extensively used [37]. A simple spot test to find out the presence of iron(III) in filtrate is reported, which involves the use of KSCN solution, which gives red color with iron(III) [38] (1 drop of filtrate +1 drop of $2 \mathrm{~N} \mathrm{H}_{2} \mathrm{SO}_{4}+1$ drop of thiocyanate, $\mathrm{HCl}$ is avoided as it gives dense fumes of $\mathrm{NH}_{4} \mathrm{Cl}$ ). Absence of red color indicates that iron (III) precipitation is almost complete. About $2.5 \mathrm{~mL}$ of the above prepared solution was taken and was oxidized from chromium (III) to chromium (VI) [39] by adding $3 \mathrm{~mL}$ of bromine water and boiling for $3 \mathrm{~min}$ to ensure the complete oxidation of chromium. The solution was cooled and diluted to volume in a $100-\mathrm{ml}$ standard flask. An aliquot of this solution was used for analysis by the proposed method. The results indicate that there is no significant difference, as indicated by $\mathrm{t}$ and $\mathrm{F}$ values at $95 \%$ confidence limit [40], between the mean values or variances obtained by the proposed and the reference methods. The results are presented in Table 2.

\section{Conclusions}

The proposed methods for the spectrophotometric determination of hexachromium in environmental samples like, water and soil samples using two new electrophilic coupling spectrophotometric reagents, 2-amino-2',5dichlorobenzophenone (MCB) and 2-amino-5chloro-2'-fluorobenzophenone (MFB) and first-ever use phenoxazine (PNZ) are advantageous over many of the reported methods due to its sensitivity, rapidity, precision and good agreement with the official methods. Furthermore, the methods are applicable to a wide range of concentration, beside being less time consuming and do not require strictly controlled experimental conditions.

The proposed methods have been successfully applied for the determination of chromium(VI) in soil, water and selected biological samples. Statistical analysis of the results proved that the proposed methods give very accurate and reproducible values comparable to standard reference method. so, the two new proposed methods may be recommended for routine and quality control analysis of the hexavalent chromium in bulk and environmental samples.

\section{References}

* E-mail address: mansour0498@yahoo.com [1]. C. Shujuan, Z .Xinshen, Y. Lingyun, W. Li and L. Hui, Spectrochim. Acta Part A, 88, 49 (2012)

[2]. T. Madrakian, A. Afkhami and M. Mohammadnejad, Bull. Korean Chem. Soc., 30, 1252 (2009)

[3]. M.K. Jamali, T.G. Kazi, M.B. Arain, H.I. Afridi, N. Jalbani and A.R.Memon, J. Agron. Crop Sci. 193, 218 (2007)

[4]. M. Pouzar,. M. Prusov, P. Prokopcakov,. T. Cernohorsky, J. Wiener and A. Krejcov, J.Anal. at. Spectrom., 24, 685 (2009)

[5]. S.-A Waraporn, T. Jirasak, L. Haifang and L. Jin-Ming, Talanta, 71, 2062 (2007)

[6]. A. Melissa, P. Singer, H. Joseph and Aldstadt, Microchem. J., 74, 47 (2003)

[7]. A. S.-M. Raul, M. Jesus Gismera, M. Teresa Sevilla and R. P. Jesus, Sensors and Actuators B, 143,716 (2010) 
[8]. A.K. Singh, V.K. Gupta and B. Gupta, Anal. Chim. Acta, 585, 171 (2007)

[9]. K. Aslihan, K. Esra, S. Mustafa and E. Latif, J. Hazard Mater., 173, 433 (2010)

[10]. B. Áron, K. Roland and P. József, Microchem .J., 85, 103 (2007)

[11]. J. Vertick and R. Cornelis, Anal. Chim. Acta, 116, 217 (1980)

[12]. J.N. Eckert, R.J. Judd, P.A. Lay and A.D. Symons, Anal. Chim. Acta, 255, 31 (1991)

[13]. S. Subrahmanyam and M.C. Eshwar, Mikrochim. Acta II, 14, 579 (1976)

[14]. W.B. Ferng, and G.A. Parker, Anal. Chem., 304, 382 (1980)

[15]. S. un Fu-Sheng, Talanta, 30, 446 (1980)

[16]. A.J. Buscarons , Anal. Chim. Acta, 16, 452 (1957)

[17]. E. Jacobsen and W. Land, Anal. Chim. Acta, 36, 135 (1996)

[18]. J.B. Raj and H.S. Gowda, Analyst (Cambridge,U.K), 120, 1815 (1995)

[19]. M. Kamburova, Talanta, 40, 707 (1993)

[20]. B. Narayana and C. Tom, J. Braz. Chem. Soc. 16, 197 (2005)

[21]. M. Telepcakova, V. Andruch and I.S. Baloch, Chem.Pap., 59, 109 (2005)

[22]. N. Rajesh, B. Deepthi and S. Archana, J. Hazard Mater., 144, 464 (2007).

[23]. H.D. Revanasiddappa and T.N. Kiran Kumar, Talanta, 60, 1-8 (2003)

[24]. H. Gurleyuk and D.J. Wallschlaeger, Anal. Atom. Spectrom, 16, 926 (2001)
[25]. A. Makishima, K. Kobayashi and E. Nakamura, Geostandards Newsletter, 26, 41 (2002)

[26]. S. Balasubramanian and V. Pugalenthi, Talanta, 50, 457 (1999).

[27]. T.Y. Peng, Z.C. Jiang, B. Hu and H. Liao, Fresen. J. Anal. Chem., 364, 551 (1999)

[28]. A. Gaspar, C. Sogor and J. Posta, Fresen. J. Anal. Chem., 363, 480 (1999)

[29]. N. Amin, H. Okada,S. Itoh, T. Suzuki, S. Kaneso and K. Ohta, Fresen. J. Anal. Chem., 371, 1130 (2001)

[30]. C.L.Luke, Anal. Chem, 30, 2050 (1958)

[31].H. Marchart, Anal. Chim. Acta, 30, 11 (1964)

[32]. W.G. Bryson and C.M. Goodall, Anal Chim Acta, 124, 391 (1981).

[33]. P.F. Urone, Anal. Chem., 27, 1355 (1955).

[34]. B.E. Saltzman, Anal. Chem., 24, 1016 (1952).

[35]. I.G. Vazhenin, Methods of Determination of Trace Elements in Soils, Plants and Waters, Kolos, Moscow, (1974)

[36]. M. Kamburova, Talanta, 40, 719 (1993)

[37]. S. Suresh, M.F. Silwadi and A.A. Syed, Intern. J. Environ. Anal. Chem., 82, 289 (2002)

[38]. E.B. Sandell, Colorimetric Determination of Traces of Metals, $3^{\text {rd }}$ Ed., Interscience, New York (1959)

[39]. W. Mertz, Phys. Rev., 49, 163 (1969).

[40]. J.C. Miller and J.N. Miller, Statistics for Analytical Chemistry, Ellis Horwood, Chichester, 1993.

Submitted: June $9^{\text {th }} 2012$

Accepted in revised form: November $20^{\text {th }} 2012$ 